\title{
Comparative study on haematological traits of endangered Andaman wild pig and other indigenous pig breeds available at Andaman and Nicobar I slands, I ndia
}

\author{
Arun Kumar De, A. Kundu, M.S. Kundu, Jai Sunder and S. Jeyakumar \\ Central Agricultural Research Institute, \\ Indian Council of Agricultural Research, Port Blair, Andaman and Nicobar Islands, India \\ Corresponding author: Arun Kumar De, email: biotech.cari@gmail.com \\ Received: 01-07-2013, Revised: 16-07-2013, Accepted: 17-07-2013, Published online: 28-08-2013
}

doi: 10.14202/vetworld.2013.794-798 How to cite this article: De AK, Kundu A, Kundu MS, Sunder J and Jeyakumar S (2013) Comparative study on haematological traits of endangered Andaman wild pig and other indigenous pig breeds available at Andaman and Nicobar I slands, India, Veterinary World 6(10): 794-798.

\begin{abstract}
Aim: The present experiment was conducted to investigate and compare the haematological parameters of different pig breeds available at Andaman and Nicobar Islands, India viz. Andaman wild pig, Nicobari pig, Andaman desi pig and Large White Yorkshire (LWY). Six erythrocyte traits, seven leukocyte traits and four platelet traits were assessed.

Materials and Methods: $10 \mathrm{ml}$ blood was collected from each adult pig via external jugular vein aseptically in a collection tube containing anticoagulant EDTA ( $2 \mathrm{mg}$ EDTA $/ \mathrm{ml}$ of blood). All these haematological parameters were measured by an instrument named Cell Counter Analyzer MS9-5V (Melet Schloesing Laboratories).

Results: A significantly ( $\mathrm{p}<0.05)$ higher Red Blood Cell Concentration (RBC in $\left.10^{6} / \mu 1\right)$, Packed Cell Volume (PCV in \%) and Haemoglobin concentration $(\mathrm{Hgb}$ in $\mathrm{g} / \mathrm{dl}$ ) was found in Andaman wild pig in comparison to all other pig breeds. The Total White Blood Cell Concentration (WBC in $10^{3} / \mu \mathrm{l}$ ) was significantly $(\mathrm{P}<0.05)$ higher in Andaman wild pig in comparison to all the other pig breeds studied. The ratio of Neutrophil and Lymphocyte (N:L) was lowest in Andaman wild pig and was highest in LWY. No significant difference $(\mathrm{P}<0.05)$ was found in total Blood Platelet Concentration (PLT in $\left.10^{3} / \mu 1\right)$ between Andaman wild pig and LWY but the values were significantly higher in comparison to Andaman desi pig and Nicobari pig.
\end{abstract}

Conclusions: The haematological parameters of different pig breeds available at Andaman and Nicobar Islands were investigated and compared and based on haematological parameters it was found that Andaman wild pig is best adapted in the hot humid climate of Andaman and Nicobar Islands and Large White Yorkshire is least adapted.

Keywords: adaptability, Andaman desi pig, Andaman wild pig, haematology, Nicobari pig

\section{I ntroduction}

Blood plays the vital role of transporting nutrients to every cell of our body and fulfills the regulatory, protective and homeostatic functions in mammals [1]. Haematological profiles are important indicators of health and disease in both human beings as well as in animals and have been used routinely as a guide in the diagnosis, treatment and prognosis of many diseases [2]. Almost every change that takes place in the mammalian body is reflected in the blood. Hence, determination of blood profiles reflects the physiological responsiveness of the animals to its internal and external environment [3]. Change in haematological parameters is also an important tool to access the level of stresses due to environment and nutritional factors [4].

The Andaman \& Nicobar Islands are a group of 572 big and small Islands \& Islets in the South eastern part of Bay of Bengal. The temperature of these Islands varies from $27^{\circ} \mathrm{C}$ to $30^{\circ} \mathrm{C}$. The annual rainfall of these Islands is about $3100 \mathrm{~mm}$ and enjoys a tropical hot humid climate [5]. Pigs constitute $27.26 \%$ of the total livestock (cattle, goat, buffalo and pig) of Andaman

Copyright: The authors. This article is an open access article licensed under the terms of the Creative Commons Attribution License (http://creativecommons.org/licenses/by/2.0) which permits unrestricted use, distribution and reproduction in any medium, provided the work is properly cited. and Nicobar Islands and mostly reared by the tribes and native people of Andaman and Nicobar Islands [5]. There are four different genetic groups of pigs available in these Islands. They are Andaman wild pig, Nicobari pig, Andaman desi pig and pure and cross breeds of Large White Yorkshire (LWY). The Andaman wild pig (Sus scrofa andamanensis), an endangered pig germplasm of Andaman and Nicobar Islands, is available in the Jarawa reserve forest area. They are being poached by the primitive Jarawa tribes and are the main source of protein for them. Nicobari pigs (Sus domesticus) locally known as Ha-un are reared by the Nicobari tribes of Nicobar Islands and serves as the main animal protein source for their livelihood. Moreover, pigs are treated as an asset and are religiously attached to Nicobari tribes. The Nicobari pig is managed under open grazing, free range systems. It normally feeds on coconut, pandanus fruits, tuber crop roots, fish waste, crab, and kitchen and vegetable waste [5]. The Andaman desi pig is mostly found in Andaman group of Islands [6]. Its body color varies from rusty grey to brown and black. The hair on the neck and back portion are thick and long and those on the flank and sides are relatively thinner and shorter. Large White Yorkshire pig is recently introduced in these Islands but their adaptability to the local 
Table-1. Comparative Erythrocytic parameters of different pig breeds of Andaman and Nicobar Islands

\begin{tabular}{lllll}
\hline Parameters & Andaman wild pig $(\mathbf{n}=\mathbf{3})$ & Nicobari pig $(\mathbf{n}=\mathbf{1 0})$ & Andaman desi pig $(\mathbf{n}=\mathbf{1 0})$ & LWY \\
\hline RBC $\left(10^{6} / \mu \mathrm{l}\right)$ & $\left.9.72 \pm 0.17^{\mathrm{A}}\right)$ \\
MCV (f1) & $63.1 \pm 0.8^{\mathrm{A}}$ & $4.52 \pm 0.93^{\mathrm{C}}$ & $5.44 \pm 0.95^{\mathrm{C}}$ & $7.43 \pm 0.78^{\mathrm{B}}$ \\
PCV (\%) & $61.3 \pm 0.56^{\mathrm{A}}$ & $63.97 \pm 1.82^{\mathrm{A}}$ & $52.78 \pm 1.23^{\mathrm{C}}$ & $55.66 \pm 2.58^{\mathrm{B}}$ \\
MCH (pg) & $17.77 \pm 0.17^{\mathrm{B}}$ & $28.89 \pm 6.08^{\mathrm{C}}$ & $28.64 \pm 4.72^{\mathrm{C}}$ & $41.35 \pm 4.46^{\mathrm{B}}$ \\
MCHC (g/dl) & $28.17 \pm 0.33$ & $18.48 \pm 1.82^{\mathrm{A}}$ & $15.80 \pm 0.42^{\mathrm{BC}}$ & $15.22 \pm 3.09^{\mathrm{C}}$ \\
$\mathrm{Hgb}(\mathrm{g} / \mathrm{dl})$ & $17.27 \pm 0.35^{\mathrm{A}}$ & $29.64 \pm 1.13$ & $29.94 \pm 0.35$ & $27.43 \pm 5.64$ \\
\hline
\end{tabular}

RBC: Red Blood Cell; MCV: Mean Corpuscular Volume; PCV: Packed cell Volume; MCH: Mean Corpuscular Haemoglobin; MCHC: Mean Corpuscular Haemoglobin Concentration; Hgb: Haemoglobin concentration, Values are presented as Mean \pm Standard Deviation, ${ }^{A, B, C}$ Values within the same row with different superscripts differ significantly $(P<0.05)$.

environment needs to be evaluated.

The pig is not only an economically important livestock animal but also a valuable animal model for biomedical research and xenotransplantation. Reference values for clinical, biochemical and haematological parameters are required for accurate data interpretation while using a pig model [7]. Blood profiles of the indigenous pig breeds of Andaman and Nicobar Islands are very essential for accurate interpretation of haematological tests and for evaluation of the adaptability of the pigs to the local environment. As no information on these aspects was available, the present study was designed to determine and compare the different haematological parameters of the pig genotypes available in these Islands.

\section{Materials and Methods}

Ethical approval: All the present experiments comply with all relevant institutional and national animal welfare guidelines and policies. Blood samples from Andaman wild pig were collected with the official permission from the Department of Environment and forest, A\& NAdministration.

Animals: In the present study, haematological parameters were compared among four genetic groups of pigs available in Andaman and Nicobar Islands. Among them three were indigenous to these Islands viz. Andaman wild pig, Nicobari pig and Andaman desi pig; and Large White Yorkshire was recently introduced to these Islands. Andaman wild pigs were maintained in Mini Zoo, Hadoo, and South Andaman. Nicobari pigs were reared by Nicobari tribes of Nicobar Islands, Andaman desi pigs were reared by the native people of Andaman and LWY pigs were maintained in our Institute farm.

Sampling procedures and measurement of haematological traits: For each adult pig, $10 \mathrm{ml}$ blood was collected via external jugular vein in a collection tube containing anticoagulant EDTA ( $2 \mathrm{mg}$ EDTA/ml of blood). Haematological traits which consist of mainly three components, including erythrocyte traits, leukocyte traits and platelet traits were measured. The blood parameters include 6 erythrocyte traits (Red Blood Cell Concentration (RBC in $10 \% / \mu 1$ ), Haemoglobin (Hgb in g/dl), Packed cell Volume (PCV in \%), Mean Corpuscular Volume (MCV in fl), Mean Corpuscular Haemoglobin ( $\mathrm{MCH}$ in pg) and Mean Corpuscular Haemoglobin Concentration (MCHC in g/dl)), 7 leukocyte traits (White Blood Cell Concentration (WBC in $10^{3} / \mu \mathrm{l}$ ), Lymphocyte percentage (Lym\%), Monocyte Percentage (Mon\%), Neutrophil percentage (Neu\%), Eosinophil percentage (Eos\%), Basophil percentage (Bas\%) and ratio of Neutrophil and Lymphocyte (N:L) and 4 platelet traits (Blood Platelet count (PLT in $10^{3} / \mu 1$ ), Mean Platelet Volume (MPV in fl), Platelet Distribution Width (PDW), Plateletocrit (Pct in \%). All these haematological parameters were measured by using Cell Counter Analyzer MS9-5V (Melet Schloesing Laboratories).

Statistical analysis: All the data collected were analyzed with the SAS Software Release 8.2 (SAS Inst., Inc., Cray, NC) with the Proc GLM and Proc CORR procedures. The differences between treatments were analyzed using a one way analysis of variance (ANOVA). Differences with a confidence level of 0.05 or less were considered to be significant.

\section{Results}

Erythrocytic values: The comparative erythrocytic parameters are presented in Table-1. A significantly ( $\mathrm{p}<0.05$ ) higher RBC, PCV and $\mathrm{Hgb}$ was found in Andaman wild pig in comparison to all other pig breeds viz. Nicobari pig, Andaman desi pig and LWY. The RBC, PCV and Hgb of LWY were significantly higher $(\mathrm{p}<0.05)$ as compared to Andaman desi pig and Nicobari pig. No significant $(\mathrm{p}<0.05)$ differences in $\mathrm{RBC}, \mathrm{PCV}$ and $\mathrm{Hgb}$ were found between Andaman desi pig and Nicobari pig. The MCV of Andaman wild pig and Nicobari pig did not differ significantly $(\mathrm{p}<0.05)$ but both were significantly higher in comparison to Andaman desi pig and LWY. Whereas, $\mathrm{MCH}$ of Nicobari pig was found significantly $(\mathrm{p}<0.05)$ higher in comparison to all the other pig breeds, the value was lowest in LWY. No significant differences were found in MCHC values among different pig breeds.

Leukocytic values: The comparative leukocytic parameters are presented in Table-2. The WBC was significantly $(\mathrm{p}<0.05)$ higher in Andaman wild pig in comparison to all the other pig breeds studied and was lowest in LWY. Whereas, LWY had significantly $(\mathrm{p}<0.05)$ lower Lym\% in comparison to all the other pig breeds, no significant difference was found among Andaman wild pig, Nicobari pig and Andaman desi pig. A significantly $(\mathrm{p}<0.05)$ higher Mon\% was found in LWY as compared to all the other pig breeds. 
Table-2. Comparative leucocytic parameters of different pig breeds of Andaman and Nicobar Islands

\begin{tabular}{lllll}
\hline Parameters & Andaman wild pig (n=3) & Nicobari pig $(\mathbf{n}=\mathbf{1 0})$ & Andaman desi pig $(\mathbf{n}=\mathbf{1 0})$ & LWY $(\mathbf{n = 1 2})$ \\
\hline WBC $\left(10^{3} / \mu \mathrm{l}\right)$ & $35.12 \pm 2.05^{\mathrm{A}}$ & $17.38 \pm 2.63^{\mathrm{B}}$ & $11.63 \pm 3.16^{\mathrm{C}}$ & $5.76 \pm 1.79^{\mathrm{D}}$ \\
Lymphocytes\% & $62.80 \pm 0.36^{\mathrm{A}}$ & $67.84 \pm 4.09^{\mathrm{A}}$ & $65.23 \pm 3.22^{\mathrm{A}}$ & $48.62 \pm 9.50^{\mathrm{B}}$ \\
Monocytes\% & $8.37 \pm 0.15^{\mathrm{B}}$ & $7.30 \pm 2.03^{\mathrm{B}}$ & $8.13 \pm 1.57^{\mathrm{B}}$ & $11.55 \pm 4.05^{\mathrm{A}}$ \\
Neutrophils\% & $4.80 \pm 0.72^{\mathrm{C}}$ & $16.18 \pm 2.59^{\mathrm{B}}$ & $17.58 \pm 1.49^{\mathrm{B}}$ & $36.67 \pm 12.19^{\mathrm{A}}$ \\
Eosinophils\% & $21.37 \pm 1.07^{\mathrm{A}}$ & $6.61 \pm 3.14^{\mathrm{B}}$ & $6.86 \pm 3.68^{\mathrm{B}}$ & $0.43 \pm 0.38^{\mathrm{C}}$ \\
Basophils\% & $0.70 \pm 0.10$ & $0.72 \pm 0.21$ & $0.62 \pm 0.13$ & $1.00 \pm 0.79$ \\
Neutrophils:Lymphocytes $0.08 \pm 0.01$ & $0.24 \pm 0.04$ & $0.27 \pm 0.03$ & $0.83 \pm 0.43$ \\
\hline
\end{tabular}

Values are presented as Mean \pm Standard Deviation

$A, B, C, D$ Values within the same row with different superscripts differ significantly $(P<0.05)$.

Table-3. Comparative thrombocytic parameters of different pig breeds of Andaman and Nicobar Islands

\begin{tabular}{llll}
\hline Parameters & Andaman wild pig (n=3) & Nicobari pig (n=10) & Andaman desi pig (n=10) \\
\hline PLT $\left(10^{3} / \mu l\right)$ & $696.00 \pm 4.00^{\mathrm{A}}$ & $183.20 \pm 58.01^{\mathrm{B}}$ & $212.00 \pm 7.52^{\mathrm{B}}$ \\
MPV $(\mathrm{f} 1)$ & $6.83 \pm 0.35^{\mathrm{A}}$ & $6.74 \pm 1.04^{\mathrm{A}}$ & $6.66 \pm 0.34^{\mathrm{A}}$ \\
PCt $(\%)$ & $0.43 \pm 0.21^{\mathrm{A}}$ & $0.14 \pm 0.05^{\mathrm{B}}$ & $0.30 \pm 0.16^{\mathrm{AB}}$ \\
PDW & $11.90 \pm 0.36^{\mathrm{AB}}$ & $11.88 \pm 0.59^{\mathrm{AB}}$ & $12.08 \pm 0.29^{\mathrm{A}}$ \\
\hline
\end{tabular}

PLT: platelet count; MPV: Mean Platelet Volume; Pct: Plateletocrit; PDW: Platelet Distribution Width;

Values are presented as Mean \pm Standard Deviation

$A, B, C, D$ Values within the same row with different superscripts differ significantly $(P<0.05)$.

Andaman wild pig had significantly $(\mathrm{p}<0.05)$ lower $\mathrm{Neu} \%$ in comparison to all the other pig breeds; the value was highest in LWY. Eos\% was highest in Andaman wild pig followed by Andaman desi pig, Nicobari pig and LWY. No significant differences were found in Bas\% among all the pig breeds studied. The $\mathrm{N}$ and $\mathrm{L}$ ratio was lowest in Andaman wild pig and was highest in LWY. The MCV of Andaman wild pig was also significantly $(\mathrm{p}<0.05)$ higher in comparison to Andaman desi pig and LWY.

Thrombocytic values: The comparative thrombocytic parameters are presented in Table- 3 . No significant $(p<0.05)$ difference was found in PLT between Andaman wild pig and LWY but the values were significantly higher in comparison to Andaman desi pig and Nicobari pig. MPV value of LWY was significantly $(\mathrm{p}<0.05)$ lower in comparison to all the other pig breeds studied. Pct of Andaman wild pig was significantly $(\mathrm{p}<0.05)$ higher than Nicobari pig and LWY but did not differ significantly with Andaman desi pig. PWD of LWY was lowestamong all the breeds studied.

\section{Discussion}

Haematological traits are essential parameters for evaluating the health status of individual animals and herds [8]. Haematological parameters are good indicators of the physiological and pathological changes in the animals [9-10], and are also an excellent medium for the measurement of potential biomarkers [11].

In the present study, significantly higher values of $\mathrm{RBC}, \mathrm{PCV}$ and $\mathrm{Hgb}$ were found in Andaman wild pig in comparison to all other pig breeds (Table-1). Higher values of RBC, $\mathrm{Hgb}$ and PCV were reported in wild boar by Harapin et al. [12] and in wild piglets by Tusek et al. [13]. Higher PCV value was also reported in Javan warty pig (Sus verrucosus), an endemic pig to Java and Bawean Islands [14]. Elevations of Hgb, PCV and RBC often occur with physical exertion resulting into hemoconcentration [15]. In the present study, the samples were collected from wild pigs maintained in Mini-zoo provided with sufficient food and water which excludes the possibility of hemoconcentration as a cause of higher values of PCV, Hgb and RBC. It may be hypothesized that the higher values of $\mathrm{Hgb}$, $\mathrm{PCV}$ and $\mathrm{RBC}$ indicate an enhanced need for oxygen as wild pig is fast runner. MCV of Andaman wild pig and Nicobari pig was significantly higher in comparison to Andaman desi pig and LWY. Higher values of MCV in wild pigs impute an enhanced need for oxygen [13]. The Nicobari pigs are managed by the Nicobari tribes under open grazing, free range systems and are fast runner. The enhanced need for oxygen is indicated by their high value of MCV. MCV, MCH and MCHC values were reported to decrease and $\mathrm{RBC}, \mathrm{Hgb}$ and $\mathrm{PCV}$ values were reported to increase in pig after vaccination [16]. Whereas no significant differences were found in RBC and PCV values among Landrace, Large White and Songliao Black pig breeds, a significant decrease in $\mathrm{Hgb}$ in large White in comparison to Landrace and Songliao Black pig was found [16]. In the present study, RBC and PCV value of LWY was found higher than that reported by Liu et al. [16]. This may be due to environmental effect on haematological traits as haematological and biochemical values may be affected by a wide range of factors, including environment, season, diet, age and stress [12].

In the present study, the WBC was significantly higher in Andaman wild pig in comparison to all the other pig breeds studied (Table-2) and was higher than the physiological level $\left(11-22 \times 10^{6} / \mu \mathrm{l}\right)$. The WBC count of Andaman wild pig was higher than that reported in wild boar of Croatia $\left(9.79 \pm 4.27 \times 10^{6} / \mu \mathrm{l}\right)$ [12]. The WBC count was found lowest in LWY. The WBC count of pigs from Southeastern Nigeria was reported to be $25.92 \pm 8.08 \times 10^{6} / \mu 1$ [17]. In the present study, the WBC count of Andaman desi pig, Nicobari pig and LWY were lower than that reported in Nigerian 
pig. Leucocytosis in animals has been attributed to stress [18] and is suggested to be due to mobilization of leukocyte from their pool to the peripheral circulation apparently due to inhibitory role on circulating corticosteroids which is known to increase in animals under stress and cause leukocytosis [11]. In the present study as the wild pigs were maintained in zoo away from their natural habitat, they were under stress which was evident from their high leukocyte value.

No significant $(\mathrm{p}<0.05)$ difference was found in PLT between Andaman wild pig and LWY but the values were significantly higher in comparison to Andaman desi pig and Nicobari pig (Table-3). The PLT count of Andaman wild pig and LWY was similar to that of reported in minipigs of Denmark by Olsen et al. [19].

The ratio of neutrophil and lymphocyte $(\mathrm{N}: \mathrm{L})$ is the most common index of measurement of stress and adaptability of the animals to the local environment, which generally increases under stress condition [20]. Decreases in L and eosinophils and increase in $\mathrm{N}$ occur in pigs under stress such as following marketing [21], and electric shock [22]. In the present study, $\mathrm{N}$ and $\mathrm{L}$ ratio was lowest in Andaman wild pig followed by Nicobari pig, Andaman desi pig and LWY (Table-2). It might be hypothesized that Andaman wild pig is best adapted in the hot humid climate of Andaman and Nicobar Islands and Large White Yorkshire is least adapted.

\section{Conclusion}

In conclusion, we investigated and compared the haematological parameters of different pig breeds available at Andaman and Nicobar Islands. The results of the study will be helpful for accurate interpretation of haematological tests of the pig genotypes of Andaman and Nicobar Islands.

\section{Author's contributions}

AKDe, SJ and MSK were involved in the design of the experiment. The experiment was done by AKDe and JS. AK revised the final draft of manuscript. All authors read and approved the final manuscript.

\section{Acknowledgements}

Authors are very much thankful to Dr. Shiv Kumar, Senior Veterinary Officer, Car Nicobar and Dr. Senthil Kumar, Deputy Conservator of Forests, Andaman and Nicobar Administration for their kind help in collection of blood samples from Nicobari pig and Andaman wild pig. Authors are also thankful to Director, Central Agricultural Research Institute, Port Blair, Andaman and Nicobar Islands for providing fund to carry out the study.

\section{Competing interests}

The authors declare that they have no competing interests.

\section{References}

1. Nasyrova, D. I., Sapronova, A. Y., Nigmatullina, R. R. and
Ugryumov, M. V. (2006) Changes in blood plasma volume in rats during ontogenesis. Russ. J. Dev. Biol. 27: 1062-3604.

2. Talebi, A., Asri-Rezaei, S., Rozeh-Chai, R. and Sahraei, R. (2005) Comparative Studies on Haematological Values of Broiler Strains (Ross, Cobb, Arbor-acres and Arian). Int. J. Poultry Sci. 4 (8): 573-579.

3. Esonu, B. O., Enenalom, O. O., Udedibie, A. B. I., Herbert, U., Ekpor, C. F., Okoli, I. C. and Iheukwumere, F. C. (2001) Performance and blood chemistry of weaner pigs fed raw mucuna (velvet bean) meal. Trop. Anim. Pro. Invest. 4: 4955.

4. Mmereole, F. U. C. (2008) The effects of replacing groundnut cake with rubber seed meal on the haematological and serological indices of broilers. Int. J. Poult Sci. 7(6): 622-624.

5. Kundu, A., Sunder, J., Jeyakumar, S., Verma, S. K., Kundu, M. S., De, A. K. and Srivastava, R. C. (2010) Livestock and poultry production policy for Andaman and Nicobar Islands: a scientific perspective. Published by Director, CARI, Port Blair. pp 1-48.

6. De, A. K., Jeyakumar, S., Kundu, M. S., Sunder, J., Kundu, A. and Verma, S. K. (2011) Microsatellite analysis of indigenous pig breeds of Andaman and Nicobar Islands-a preliminary study, International Conference on Tropical Island Ecosystems: 151-152.

7. Chen, Y., Qin, S., Ding, Y., Li, S., Yang, G., Zhang, J., Li, Y., Cheng, J. and Lu, Y. (2011) Reference values of biochemical and hematological parameters for Guizhou minipigs. Exp. Biol. Med. 236: 477-482.

8. Gong, Y. F., Lu, X., Wang, Z. P., Lu, F. and Luo, Y. R. (2010) Detection of quantitative trait loci affecting haematological traits in swine via genome scanning. BMC Genetics 11: 5656.

9. Oguike, M. A., Ilo, S. U. and Odika, I. E. (2011) Physiological Responses of Gilt to Supplementation of Selenium and Vitamin E. J. Adv. Dev. Res. 2 (1): 115-122.

10. Wang, J. P., Yoo, J. S., Lee, J. H., Jang, H. D., Kim, H. J., Shin, S. O., Seong, S. I. and Kim, I. H. (2009) Effects of phenyllactic acid on growth performance, nutrient digestibility, microbial shedding, and blood profile in pigs. J. Anim. Sci. 87: 3235-3243.

11. Adenkola, A. Y., Ayo, J. O., Sackey, A. K. B. and Adelaiye, A. B. (2009) Haematological and serum biochemical changes in pigs administered with ascorbic acid and transported by road for four hours during the harmattan season. J. Cell Anim. Biol. 3(2): 021-028.

12. Harapin, I., Bedrica, L., Hahn, V., Sostaric, B. and Gracner, D. (2003) Haematological and biochemical values in blood of wild boar (Sus scrofa ferus). Veterinarski Arhiv. 73(6): 333-343.

13. Tusek, T., Mihelic, D., First, L., Janicki, Z. and Opancar, D. (1994) Komprativni prikaz crvene krvne slike divljei domace europske svinje. Vet. Stanica 25: 81-84.

14. Semiadi, G. and Nugraha, R. T. P. (2009) Some Notes on Biological Aspects of Captive Javan Warty Pig (Sus verrucosus). Biodiversitas 10(3): 124-128.

15. Delgiudice, G. D., Krausman, P. R., Bellantoni, E.S., Wallace, M. C., Etchberger, R. C. and Seal, U. S. (1990) Blood and urinary profiles of free-ranging desert mule deer in Arizona. J. Wildlife Dis. 26: 83-89.

16. Liu, Y., Luo, Y. R., Lu, X., Qui, X. T., Fu, W. X., Zhou, J. P., Liu, X. Y., Zhang, Q. and Yin, Z. J. (2010) Investigation and comparative study on haematological traits, lysozyme concentration and T lymphocyte subpopulation in three pig breeds. J.Anim. Vet. Adv. 9(21): 2748-2751.

17. Eze, J. I., Onunkwo, J. I., Shoyinka, S. V. O., Chah, F. K., Ngene, A. A., Okolinta, N., Nwanta, J. A. and Onyenwe, I. W. (2010) Haematological profiles of pigs raised under intensive management system in south-eastern Nigeria. Nigerian Vet. J. 31 (2): 115-123.

18. Buckham-Sporer, K. R., Weber, P. S., Burton, J. L., Earley, B. and Crowe, M. A. (2008) Transportation of young beef bulls 
alters circulating physiological parameters that may effective biomarkers of stress. J. Anim. Sci. 86: 1325-1334.

19. Olsen, A. K., Bladbjerg, E. M., Jensen, A. L. and Hansen, A. K. (2000) Effect of pre-analytical handling on haematological variables in minipigs. Lab. Anim. 35: $147-$ 152.

20. Minka, N. S. and Ayo, J. O. (2007) Physiological responses of transported goats treated with ascorbic acid during the hot dry season. Anim. Sci. J. 78(2): 164-172.
21. Clemens, E. T., Schultz, B. D., Brumm, M. C., Jesse, G. W. and Mayes, H. F. (1986) Influence of market stress and protein level on feeder pig hematologic and blood chemical values. Am. J. Vet. Res. 47:359-362.

22. Ellersieck, M. R., Veum, T. L., Durham, T. L., McYickers, W. R., McWilliams, S. N. and Lasley, J. F. (1979) Response of stress-susceptible and stress-resistant Hampshire pigs to electrical stress. II. Effects on blood cells and blood minerals. J. Anim. Sci. 48: 453-458.

$* * * * * * * *$ 